\title{
The Swanscombe Skull*
}

【N view of the importance of the discovery in 1935 and 1936 by Mr. Alvan T. Marston of two bones of a human skull, associated with implements of Acheulean type, in Pleistocene gravels of the Barnfield pit, near Swanscombe, Kent (see NaTURE of October 19, 1935, p. 637, and August 1, 1936, p. 200), a research committee was appointed by the Royal Anthropological Institute in 1937 to examine and report on the discovery in all its aspects. Further excavation was carried out on behalf of the Committee by Dr. M. Aylwin Cotton of the Institute of Archæology, the cost being borne by a grant of $£ 50$ made by the Council of the Royal Society. Publication of the report has been assisted by the Trustees of the British Museum.

The findings of the Committee are based upon reports by specialist members of the Committee, which appear as chapters, ten in number, in the report, and following a general description of the site, deal respectively with geology, palæontology, archæology, including an account of the further excavations contributed by Dr. Cotton, correlation of the deposits, the general features of the bones, their form, and the endocast of the brain.

The Barnfield pit, which is situated about half a mile to the north-west of Swanscombe, between Dartford and Gravesend, has long been famous as a rich source of the implements of palæolithic man and of the remains of Pleistocene mammals ; but no human skeletal remains had been found previously. This is also the first occasion on which human remains have been found definitely in association with an Acheulean industry not only in Britain, but in Europe generally.

The deposits belong to the Boyn Hill or $100-\mathrm{ft}$. terrace of the Thames. A uniform stratification makes it possible to recognize local sub-divisions, in sequence from above downward, of upper gravel and hill wash, upper loam, middle gravel and sands, lower loam, and lower gravel. The deposits lie in a channel, running from west to east, cut in the chalk and Thanet Sands. A subsidiary channel, or possibly scour, containing falsebedded gravel, has cut down through the lower middle gravels through the lower loam to the lower gravel. The two cranial fragments were discovered in an obliquely bedded gravel in this subsidiary channel. This seam is the lowest member in a series of eight similar seams between

* Report on the Swanscombe Skull prepared by the Swanscombe Committee of the Royal Anthropological Institute. Reprinted from the Journal of the Royal Anthropological Institute, 68, 1, 1938. Pp. $17-98+6$ plates. the lower middle gravel and the upper middle gravel series. The bones are unquestionably indigenous to the series.

The fossil mammalian remains, of which the examination by Mr. M. A. C. Hinton is not yet complete, include, according to a tentative identification, Elephas antiquus, Rhinoceros hemitoechus, Bos primigenius, Dama clactoniana-a species at present known only from Britain-and Equus caballus -a fauna predominantly of a woodland type, and of an interglacial facies.

A report on the stone industries by Mr. C. F. C. Hawkes, with the co-operation of Dr. K. P. Oakley and Mr. S. Hazzledine Warren, enters into a detailed analysis of the content of each stratum. This analysis is of importance not only as fixing definitely the place in the cultural series of the implements associated with the human remains, but also for its examination of the attribution suggested by Mr. Marston of the industries of the lower and lower middle gravels to the Chellean, or Abbevillian industry, as it is now termed.

The cultural succession, as determined by the report, definitely rules out the Abbevillian attribution, assigning the industry of the lower gravels to Clactonian II, but somewhat prior to Clactonian II of the type site. The lower loam is sterile, such implements as it contains showing evidence of exposure, and evidently having sunk through. The industry is still Clactonian, though of a somewhat more advanced type than that of the lower gravels. The industry of the lower middle gravels is characterized by the number of hand-axes. It was formerly (1912) denominated "Chelles or a transition to St. Acheul" ; but it is here assigned to Early Middle Acheulean, the Acheulean III of Breuil; while the large number of flakes may be classed as flake-products of the same Acheulean industry. A small proportion utilized still represent the Clactonian tradition.

Mr. Marston here also assigned certain of the hand-axes to the Abbevillian on the ground of the crudity of their workmanship; but it is pointed out that crudity is not necessarily an indication of relative age, and that the industry must be taken as a whole, when its essential unity appears as entirely of the Early Middle Acheulean.

The industry associated with the skull fragments is regarded as belonging to exactly the same culture as that from the lower gravels. Above the oblique seams of gravel, in which the seam containing the skull fragments is the lowest, the channel is filled by a stratum of gravelly silt, over 
which the upper middle gravel series continues in the form of horizontally bedded yellow sands, covering the channel and the lower middle gravel surface flanking it. These deposits are not rich in implements, and nothing suggesting an advance in human material culture has been recovered from them. The yellow sands are uniformly sterile and the skull layer is thus well insulated against conflation with any subsequent cultural development. This is reinforced by the upper loam which again is sterile; and only from the top surface have any further implements been obtained. Such flakes and hand-axes as are yielded by the upper loam show that at this stage the culture prevalent at Swanscombe was still Acheulean. Some advance is suggested by 'sub-cordate' or 'sub-ovate' types ; but they have never yet been found in situ in the Barnfield pit. A sign of real innovation are the primitive 'tortoise' cores associated with hand-axes in Rickson's pit, in which the earliest stage of the Levallois industry has been recognized. The whole evidence from the overlying strata confirms the inviolable association of the skull with a pure Early Middle Acheulean industry, which already, on the evidence of the artefacts alone, had been assessed by Breuil as Acheulean III.

Dr. K. P. Oakley discusses the correlation of the deposits. The gravels of the $100 \mathrm{ft}$. terrace must be diagnosed as interglacial and as younger than the Lower Chalky Boulder Clay. This is supported by the fauna and the glacial erratics. From the geological and archæological evidence no doubt can arise that the middle gravels are older than the main Combe Rock stage. If the industries correspond with Middle Acheulean III, in the Somme Valley Middle Acheulean is assigned to the Mindel-Riss interglacial, and it would seem that the middle gravels at Swanscombe must also be regarded as belonging to that period.

The anatomical and anthropological characters of the skull have been examined by Prof. W. E. Le Gros Clark and Dr. G. M. Morant. The fragments found are the occipital and left parietal. Both are nearly complete and articulate perfectly. The individual to whom the bones belonged was probably female and died in her early twenties. In two respects only do they show any significant difference from a modern skull of Homo sapiens, namely, in the unusual breadth of the occipital bone and in the thickness of the bone. The endo. cranial cast shows no feature which serves to differentiate it from the endocranial cast of modern human skulls. The series of measurements fall well within the range of the modern human female skull. The estimated cephalic index is in the neighbourhood of 78 and the cranial capacity 1,325 c.c., which would be unexceptionable in a modern female skull. The missing parts of the skull, however, might have been so formed as to provide clear evidence of differentiation from modern man.

\section{McDougall's Experiments on the Inheritance of Acquired Habits}

$\mathrm{I}^{\mathrm{N}}$ a series of papers extending over a period from 1926 until 1938, Prof. William McDougall brought together evidence which led him to suppose that the hypothesis of Lamarck concerning the inheritability of acquired characteristics is substantially correct.

In designing his experiments, McDougall kept in mind two principles which previous investigators have overlooked. These are, first, that "the adaptation investigated should be achieved by the intelligent purposive efforts of the organism concerned", and, second, that it should be of such a nature that slight degrees of adaptation should be measurable, for it has already been shown by Lamarck's opponents that acquired characteristics are not transmitted as "perfected wholes of structure or function". Hence, if Lamarckian transmission is to be found at all, it should be looked for as some "slight increase of facility in the acquisition of the modification acquired by the parent". Many generations would probably be necessary, therefore, before any very marked changes appeared.

White rats were chosen as subjects for this experiment since it was possible to obtain an initially pure strain (Wistar), and since the breeding habits of rats allow a large number of generations to be studied in a reasonable length of time. A preliminary experiment showed deterioration in performance with successive generations, due, apparently, to an increasing fear of electric shock. The final form of the experiment, therefore, was designed to develop such a phobia. To this end, an apparatus was constructed consisting of three parallel alleys, the central one serving as an entrance and the outside ones as exits to a platform. The apparatus was filled with water, and the motivation was escape from the water to a dry platform. Of the two exit alleys, one, the shocked pathway, was brightly illuminated while the other, the free pathway, was kept dim. The task confronting the animals, therefore, was to escape from the water 